Open Access

\title{
Creating political spaces at sea - governmentalisation and governability in Norwegian fisheries
}

\author{
Jahn Petter Johnsen (1)
}

\author{
Correspondence: \\ Jahn.Johnsen@uit.no \\ Norwegian College of Fishery \\ Science, UiT-the Arctic University of \\ Norway, Tromsø, Norway
}

\begin{abstract}
How do technologies of power make the world governable? The understanding of how management techniques create governability remains rather poor. In this article, I analyse how spatial regulation in Norwegian fisheries direct human behaviour towards scientific, political, and administrative objectives. Like other fisheries' regulations, they contribute to governmentalisation and governability, and this article illustrate how this happens. Governance aims towards specific outcomes, but in the attempt to make the world governable, the governing and those who are governed are changed and new social orders may be the result. Thus, governing instruments are not only instruments for the direction of behaviour, but also instruments for social change.
\end{abstract}

Keywords: Spatial management, Fisheries regulations, Governmentality, Governability

\section{Introduction}

Governance is a complex art (Jessop 1997). Despite much research on fisheries' governance organisation and instruments, there are still things to learn about how fisheries and marine governance develop and 'how power and rule' work. In addition to complex fish-quota management arrangements, Norway also uses regulation of sea space as governing instruments. The instruments are varied from technical regulation of use of gear in certain areas via specific zones for certain vessel sizes to protection areas. Some may see these regulations simply as rules for order on the fishing grounds while the quota management arrangements are the central policy instruments; but as I will show, that is not the case. The spatial regulations in Norwegian fisheries do more than just direct behaviour on the fishing grounds, they actually change the world. ${ }^{1}$ The fisheries' governance discourse has after Hardin's Tragedy of the Commons (1968) been formed around solutions founded on top-down control through state apparatuses, use of market mechanisms like transferable quotas, or on institutional set ups like co-management arrangements. (See for example: Jentoft and Kristoffersen 1989, McGoodwin 1990, Berkes 2010, Caddy and Cochrane 2001, Hannesson 2004, Arnason 2008, Ban et al. 2009, Smith et al., 2009). Scholars with institutional/organisation studies perspectives have made important contributions to governance studies (Lemke 2007) and the institutionalist inspired interactive governance has in the last decade been an influential approach in fisheries' governance studies. According to interactive

(c) The Author(s). 2017 Open Access This article is distributed under the terms of the Creative Commons Attribution 4.0 International License (http://creativecommons.org/licenses/by/4.0/), which permits unrestricted use, distribution, and reproduction in any medium, provided you give appropriate credit to the original author(s) and the source, provide a link to the Creative Commons license, and indicate if changes were made. 
governance scholars, governance is all the interactions that takes place, and governance encompasses both governing, government, and non-formal processes (Kooiman and Bavinck 2005, Jentoft and Chuenpagdee 2015a). In this approach, the conditions for governability is a key element in governance studies. Governability is the capacity of a socially constructed governing system to govern a complex system-to-be-governed (Kooiman et al. 2005, Jentoft 2007, Jentoft and Chuenpagdee 2015a, b). As it is defined, governability is about the instrumental outcome and the quality of governance in terms of addressing 'societal concerns' (Chuenpagdee and Jentoft 2015:5). In this study, I explore how spatial regulations contribute to governability and create new social orders. Hence, I also address the general question of how governance is possible. As I will show, spatial regulations are not only about the instrumental designation of sea space for different activities to create order, but they are performative instruments that change the use, practices, conceptualisations, and constructions of reality. I study how, in a broader sense, they contribute to the development of governmentality in Norwegian fisheries, and then in the next run, governability (Jentoft and Johnsen 2015). I analyse these regulations as part of the art of governing (Lemke 2007).

In the next section, I describe the theoretical framework for the analysis, followed by a section about methodology, method, and data. The fourth section presents the different regulations that I use in Section 5 to construct a typology. The last two sections are discussion and conclusions.

Theoretical approach: Governance, governability, and governmentality

Governance exists in many forms or modes from local, bottom-up self-governance to hierarchical top-down governance deploying a wide range of interventions and instruments (Jentoft et al., 1998, Ostrom 1990, Kooiman et al. 2005, Chuenpagdee and Jentoft 2015). Since there are several forms of governance (Rhodes 1996), 'governability' may contain several meanings as well. In my perspective, governing processes construct the system-to-be-governed, and in the same process, they reconfigure the governing system. Consequently, I approach interventions and instruments as tools that produce governability. However, constructions do not come out of nothing. In his studies of the history and genealogy of governing institutions and practices, Foucault (1978a) pointed out that there would always be certain mechanisms of dominance, power, and control intrinsic in all relations at all levels in the social body. In accordance with Lemke's interpretation of Foucault (Lemke 2015) and the actor-network theory (Latour 2005), I agree that practices, objectives, and choice of instruments affect production and codification of power. Further, 'the State is a practice, not a thing' (Foucault 1978b: 277), but with materiality in the form of bodies, tools, expertise, rhetoric, institutions, and so on in a physical and symbolic environment (Lemke 2015). This leads us away from an understanding of governing as simply deploying management procedures and instruments towards governing as governance with negotiations, adaptations, revisions, rearrangements of procedures and instruments, and with redistributions of power between actors. These processes take place even in situations where the State holds significant power, even if the State in itself is not the primary source of power (Foucault 1978d). In this perspective, State and power are relational products and network effects (Latour 2005). 
Inspired by Foucault (1978b) and Lemke (2007), I see system properties as something that develop in concert with the tools used to construct the system. The whole governance apparatus, science, laws, administrative procedures, and regulatory interventions are involved in construction of the system-to-be-governed at the same time as feedback and responses modify and change this apparatus. Like in the actor-network theory, I focus on how our actions, instruments, tools, and rhetoric contribute to create a representation of a relational reality that occurs as a governable system. Therefore, I approach fisheries governance as a network of evolving cybernetic mechanisms of feedback, regulation, and construction that become more or less stabilised by use of certain 'technologies of power', like spatial regulations, that are deployed to discipline and gain control over objects (Foucault 1978a, d).

In Norwegian governance, a division of labour between politics, administration, and expertise is institutionalised. The parliament decides upon the general principles, laws, and the frame for governmental action. Government and parliament define political goals in cooperation; the executive power is with the government or in the fisheries, delegated to the Fisheries Directorate or other administrative bodies. The governance is based on advice from formal experts and through collaboration with stakeholders based upon their practical expertise.

This division of labour can be translated into a conceptual model of the relationship between governance, nature, and society (Fig. 1). The model reduces real-world complexity, but is useful to illustrate how governance can be organised. ${ }^{2}$ The figure includes policymaking, decision making, administrative actions, and formal management at the top with the natural and societal interactions within fisheries constituting relations-to-be-governed. The model describes the Norwegian fisheries governance system as stable relationships, but the model is an ideal type description of functions and does not capture how the world is (Holm 1996, Johnsen et al., 2009a, Johnsen 2014). ${ }^{3}$

According to mainstream understanding, a governing system in concert with actors in the system-to-be-governed will define the reasons and objectives that legitimise intervention and regulation and the indicators to measure success. However, the reality is more complex; to govern is an 'art'. This art is what Foucault (with a concept

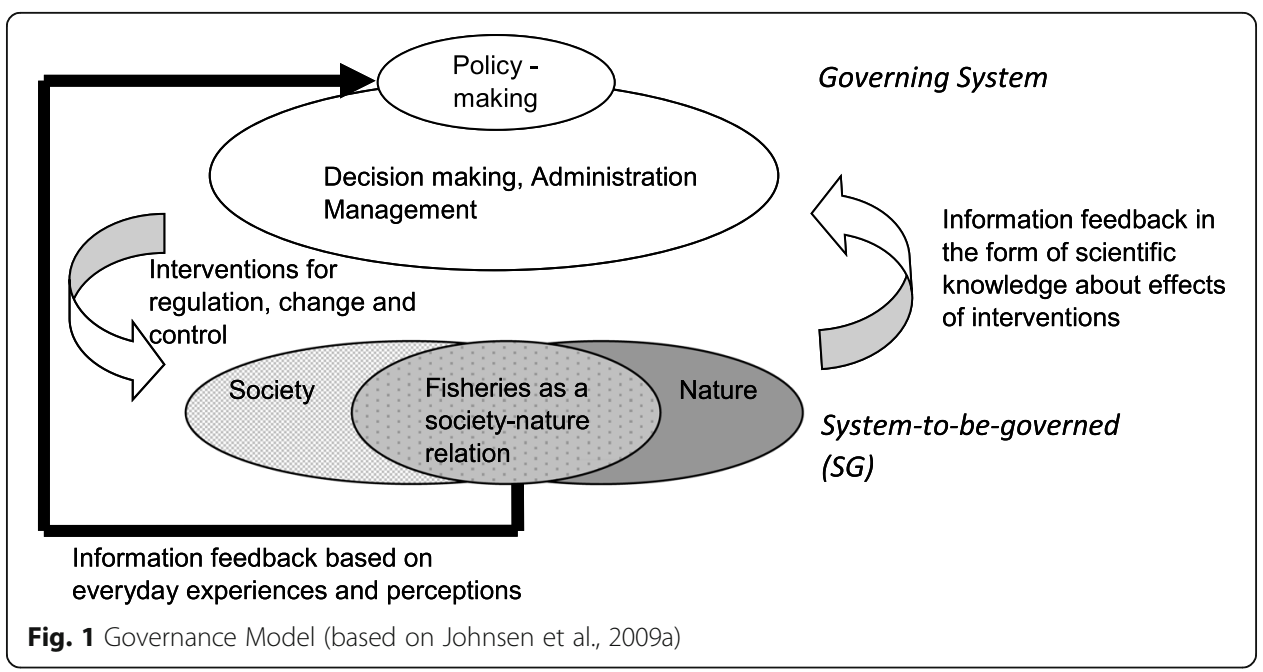


borrowed from Barthes) define as governmentality (Lemke 2001, 2007). Governmentality includes mentalities, rationalities and techniques for governing (Lemke 2001, Mayhew 2009). In Norwegian fisheries, governmentality is central for the construction of governability (Jentoft and Johnsen 2015). Governmentality is not a 'thing', but a process of governmentalisation (Foucault 1978c:109, Dean 2010): an integration of individuals, institutions, State, and Nature into a collective that shares thoughts, images, rationalities, and belief in a certain apparatus for governing. Governmentality does not come from the State, but develops with the State, the Citizens and the Territory-in our case with the formation of the socio-ecological networks that we call the fisheries. In this respect, governmentality and governability are evolving dynamic capacities, and in this article, I address how spatial regulations contribute to governmentalise the fisheries. The question that remains is how to study this.

\section{Methodology, methods and materials}

Interactive governance scholars have developed a comprehensive and holistic framework for governability assessment (Jentoft and Chuenpagdee 2015a, b). The framework rests on the assumption that governability can be analysed by breaking the governing system and the system-to-be-governed down to components and interactions, quite in line with Fig. 1. Jentoft and Chuenpagdee (2015c) illustrate that the task is not so simple, as most of the research focusses on institutional aspects and only briefly addresses all stages in the assessment framework. Despite the fact that they illustrate the limitations in holistic approaches, several of them deliver sharp analyses of how governing instruments affect governability (Høst 2015, Johnson and Pálsson. 2015). These articles point towards alternative ways of studying governability. Studies inspired by the actornetwork theory (Latour 2005), describe how management and technological change have resulted in a transformation called cyborgisation of the Norwegian fishing fleet (Holm 1996, Holm 2001, Holm and Nielsen 2004, Johnsen 2005, 2014, Johnsen et al., 2009a). ${ }^{4}$ They study how development of a quota regime in Norway have contributed to creating a governable Norwegian fisheries network. I applied a similar but not identical approach to study spatial regulations. The understanding of the Norwegian fisheries sector as an evolving network of cybernetic relations was the starting point for an analysis of spatial instruments, inspired by Foucault's (1978a, b, c) analytics of government. As a first step in the research, I explored the genealogy of and the expressed reason and rationality behind different spatial regulations used in Norwegian fisheries. I studied the history of the regulations and the arguments and rhetoric used in official documents to clarify the perspective the regulations were based on and the underlying assumptions and the knowledge they are based on to be able to clarify what was supposed to be achieved by the regulations. The documents that were analysed contain narratives that prescribe regimes of practices that shall be used, with specifications of objectives, knowledge, and regulation techniques. In other words, they present the techne, episteme and ethos of the regulations (Dean 2010). Central documents for a study of spatial management are, for example, the propositions to the Parliament for the 1857 and 1897 laws about cod fisheries in Northern Norway, called the Lofoten Laws (Prp 1857 and Prp 1897), the Marine Resources Act (2008), and the report (NOU 2005) that was prepared for the Marine Resources Act draft bill. The documents related to these four laws define the main principles for spatial management in the fisheries in 
Norway. The general support for these principles are evident from the comments submitted in the mandatory hearing of the Marine Resources Act draft bill, where all organisations and individuals in Norway could submit written comments. The hearing is summarised in the Ministry's Parliament Proposition for the Marine Resources Act (Ot. prp. nr. 20 2007-2008), and those who commented supported the draft bill. All political parties, stakeholder organisations, and the public seemed to agree on the need for the Marine Resources Act and the general principles it rests on (Anon 2008). The parliamentary debate reflected the consensus. ${ }^{5}$ Thus, the support for regulation and governing of marine resources and activities is high in Norway. The report, proposition, and hearing also sum up the former laws, former and contemporary principles, and objectives for marine resource governance in Norway as far back as the 1930s (Ot. prp. nr. 20 2007-2008, NOU 2005), ${ }^{6}$ and they even contain elements from Prp 1857 and Prp 1897. I identified the main purposes for the regulations in the Marine Resources Act and other official policy documents, laws, and regulations: for example, the contemporary and former versions of the Regulation of Professional Fishing Conduct in the Sea in Norway (FOR-2004-12-22-1878), which is a general regulation for commercial saltwater fisheries in Norway. In addition to the documents related to the Marine Resources Act, I have analysed the most recent white paper about king crab management (Meld. St. 17 2014-2015) that sums up the principles and procedures for marine resource governance. I have also studied published historical studies of the older laws and regulations. The first paragraphs of laws and regulations define the purposes and objectives and are easy to identify, but to find the arguments supporting the objectives makes it necessary to study the reports and documents they are based on. From these documents, a specific and evolving rhetoric repertoire that altogether forms a marine governance discourse can be identified. The rhetoric repertoire expresses the principles, images, procedures, and instruments for marine governance in Norway. The expression of need for governance and belief in ability to govern are evident in the reports and draft bills, the Ministry's propositions, the hearing comments, the Parliament Committee's recommendations, and the plenary debate in the Parliament. From this repertoire, it has been possible to identify categories of arguments that relate the older laws, the Marine Resources Act, regulations, and governmental documents to each other both in the past and present.

\section{History and categorisation of spatial regulations in Norway}

\section{Regulating sea space in the Lofoten cod fishery}

In 1816, the first Lofoten Law divided the most important fishing area for cod in Norway, Lofoten (Fig. 2) into 'seas' for different gear. ${ }^{7}$ The main aim was to avoid conflicts between different gear types. The law, called the 'Law of Order' gave each fishing community an exclusive territory, divided into several fields for gill nets and for long line. Each of the fields was further divided into plots for individual vessels. There were as many plots as there were boats. Jiggers (hook and hand line fishers) could fish everywhere but risked losing their hooks and lines when fishing too close to gill nets. However, in the fishing villages in Lofoten, merchants owned the land and they rented out land and houses to the fishing population for the exclusive right to buy their fish in return. Consequently, the landowners benefitted the most from this system because the fishers had no other options than to fish in the community territory and to land it 


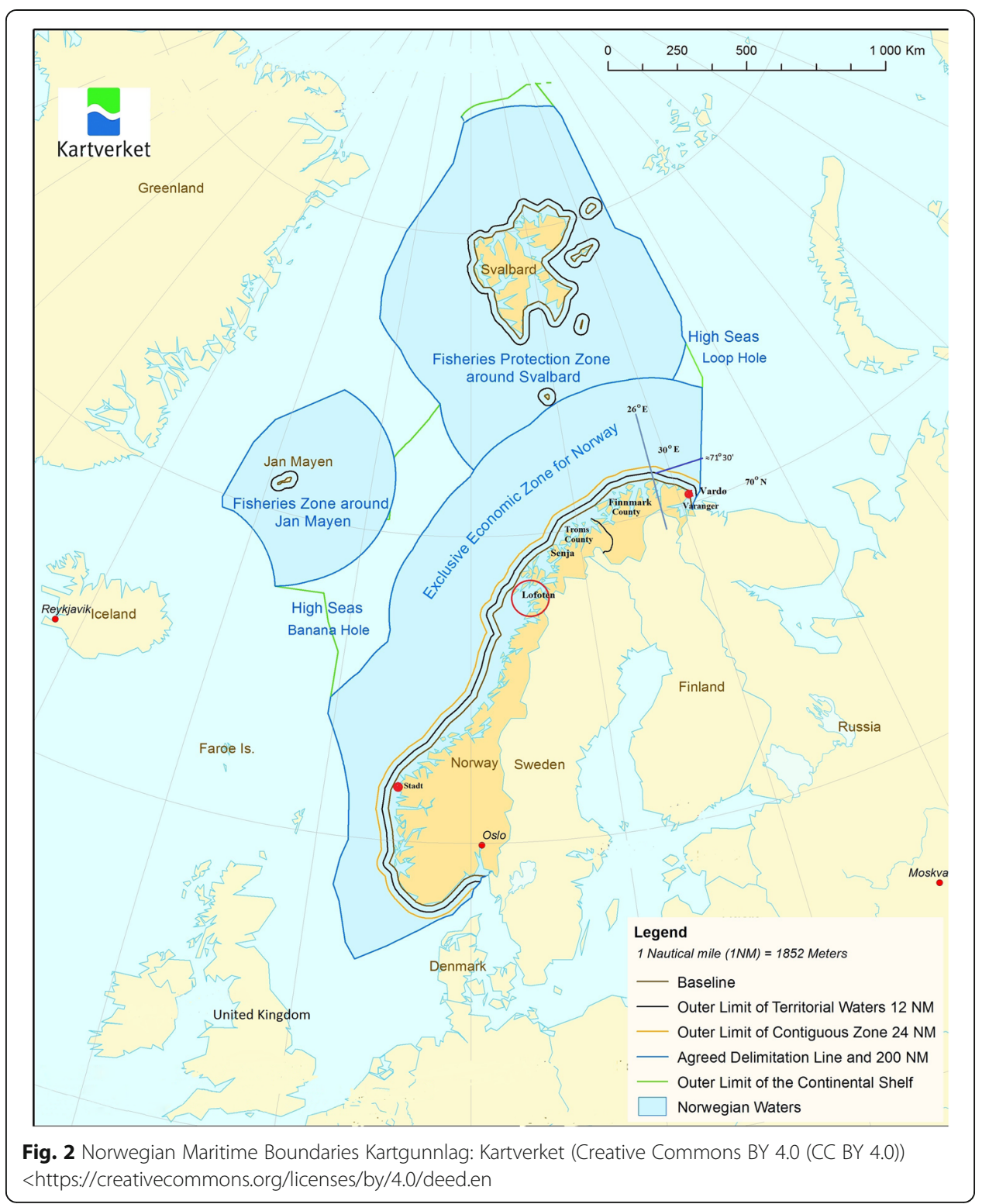

locally. Without an agreement with a landowner, it was difficult to find space for fishing. The law actually constructed the sea space as privately owned plots and made it governable by use of merchants' control over their assets. On the other hand, the law created order amongst the fishing grounds. The Law of Order was practically oriented with a focus on effectivity, even if it was a source of power and wealth to the merchants; the lawmakers had taken the competitive nature of fishery into account. The major problem with this law was that it was proposed by people with sympathy for landowners' interests and it rested upon inequality (Prp 1857). It granted little freedom to fishers and made access dependent on the merchants, making no space for a selfgoverning capacity (governmentality). The Free Law (described below) replaced the Law of Order in 1857 and changed the situation. The Free Law turned Lofoten into a free-for-all, managed top-down by the State for a period. This solution was not a success, and after the period of 'Freedom at Sea' from 1857 to 1897, the institution of 
dividing the sea space of the cod fisheries into different zones for long lining and gill netting to avoid conflicts between them was reintroduced, but now without the coupling of space to specific villages and the control of merchants. A committee of fishers elected by those who participated managed the space. Even if private control was abandoned, as we see, the Law of Order had created an institution of spatial management of importance in Norway (Prp 1896, Marine Resources Act 2008, FOR-2004-1222-1878) that became a classic example of co-management (Jentoft and Kristoffersen 1989). ${ }^{8}$ The construction of the sea into fields became a solution that survived. A capacity for self-governing was created, and governmentality and a new form of governability developed. Hence, the Law of Order period had both introduced an instrument, division of the sea, and created governmentality. Without the strait-jacket of merchant privileges that the Free Law removed, the fishers turned out to be competent and able to manage the use of space with a minimum of direct state intervention.

Nowadays, the spatial institution also includes new gear. Danish seine can now be used everywhere in Lofoten when passive gear is not in the sea. ${ }^{9}$ In some areas outside Lofoten where spatial regulations build on the same institution, the seine vessels have designated areas where they can fish. The regulations are strictly enforced if there is a potential for spatial conflicts, for example, lots of boats starting to fish in an area; but in recent years there has not been a need to appoint the committees, due to a lower number of vessels participating. Boats leave the grounds when they have fished their quota and other boats can take over the plot. Therefore, regulations have in recent years been somewhat simplified, but there is still a relatively complex regulatory underpinning, and fishers in areas or fisheries where space is an issue still have meetings before the season starts where they draw plots for where they can deploy their gear (see Additional file 1: Box S1; see also Søreng [2006]).

After the liberation of the fishers that followed from the Free Law, the spatial regulations in Lofoten and in other similar areas have worked very well (Jentoft and Kristoffersen 1989, Søreng 2006). The main purpose has been to create peace and order on the fishing grounds. The regulations have not distinguished between locals and outsiders; the grounds have been open for everybody with permission to fish and for recreational fishery. In this respect, the spatial regulations are today purely administrative arrangements to ensure that all get access and to secure peace and order on the ground. Because the fishers control it, the arrangement has also been an important example of co-management, illustrating that fishers can manage themselves under the right conditions (Jentoft and Kristoffersen 1989). On the other side, co-management success may not have been possible without a political intervention that changed the existing order, namely, the Free Law that removed merchant privileges from the constructed sea space.

\section{When sea space is a resource for change-Developing Finnmark and liberating the fishers}

Already in the late 1600s, we find area regulations with the purpose of securing local residents in Finnmark (today Norway's north easternmost county; see Fig. 2) the access to fishing grounds and to prevent them being pressed out by fishers from outside. To some extent, these arrangements were also rules of order; however, their main purpose was not to protect an existing order but to achieve political goals. In this case, to create 
order at sea was a necessary step in the process of gaining sovereignty over Finnmark, as the north easternmost territory in Norway. Finnmark has borders to Russia and Finland, and the different state formations (Sweden-Finland, Denmark-Norway, Novgorod) all struggled to gain control over the population and the territory, for example, through taxation of the indigenous population, the Sami people, and by colonisation. Colonisation followed because of economic opportunities that the States wanted to benefit from, but was also necessary to gain territorial control to be able to exploit resources and to tax the people already living there. To colonise required livelihoods for the people, and to regulate access to fishing grounds was one strategy for the State to secure the fish resources as a material foundation for settlement. Colonisation was necessary to be able to claim sovereignty over the land and the people already living there. Thus, securing access to fishing grounds was part of a political strategy to manifest the States' responsibility for the territory and people (Nedkvitne 1988, Hansen and Olsen 2004, Hutchinson 2014). Through legal means, permanent settlers and inhabitants received priority over migratory fishers to fish on the local fishing grounds. In 1702, a regulation of the trade in Finnmark prohibited migratory fishers from the south of Finnmark (called North farers) from temporarily settling in the fishing villages in Finnmark (which hindered them from fishing on the best grounds), or to fish east of Vardø (see map, Fig. 2). In addition, the regulation banned the North farers from fishing grounds or spots where the local inhabitants normally deployed their fishing lines. A new regulation in 1778 continued this ban. All these regulations may be consistent with the Finnmark people's perception (and probably that of all the people along the coast) that the local population in the fishing villages had the first priority to fish in their local area (NOU 2008:5). It is difficult to say whether the one is a result of the other or vice versa. To colonise is also to settle, and to be able to achieve settlement, the settlers must get some privileges, in this case secured through spatial interventions that, similar to in Lofoten, created the sea as a local space but without private property like privileges. We can suppose that these interventions also built governmentality among those who benefitted and turned them into citizens. As we see, spatial regulations are political tools that can have many forms. In this case, they were the means to gain control over a territory and to direct the behaviour of those who inhabited the territory, even if the regulations also produced other outcomes. The regulations bound the Citizens and the State to each other. Later, when territorial control became a less important issue, the argument for maintaining a certain order lost ground because these privileges also could prevent the most innovative fishers from access. The Law of Order actually ended access privileges outside Lofoten in 1816. The new specific arrangements for Lofoten that were established were due to the introduction of the new gears, longline and gill nets, and the special situation in Lofoten with a high number of people coming into the area. The fact that the Law of Order abolished many of the particular access privilege regulations illustrates the political purpose of these former regulations.

Even before 1830, the Norwegian authorities (Norway was not fully independent before 1905) seemed to have the view that the seas were free and that fishing was free for everyone. The Dutch lawyer Hugo Grotius launched 'The Freedom of Seas' (Mare Liberum) as a marine governance principle in 1608, declaring that the seas and marine resources should be free for all and beneficial for all. The law about fishing in Finnmark from 1830 contained this principle and made Finnmark into a free-for-all, but with 
division of the sea for different types of gear as a principle. The Lofoten regulations following the Law of Order, on the other hand, restricted The Freedom of Seas and-seen from the fishers' and the State's point of view-gave unintended privileges to landowners (Prp 1857). These privileges both abolished and established the period of the Law of Order; this obvious contradiction in the construction of sea space could not last. The Free Law was, according to Jentoft and Kristoffersen (1989), written by public officials with little insight into the practical problems of the fisheries, although the law committee leader, K. Motzfelt, had actually worked as an inspector in Lofoten for several years. Nevertheless, it represented a more radical approach to the sea than the former arrangements, and it brought the Lofoten Law into line with the more general liberal policy and with an ambition to promote some basic principles of fisheries governance (Prp 1857). Thus, in the law, the spatial regulation is not so much about territorial control as it is about the promotion of liberal thoughts that everybody should have access to the sea. The law has equity as a basic principle. The privileges of the previous Law of Order were neither consistent with the more liberal ideas that the young Norwegian State should be built on, nor with the concern for the fishing population's wellbeing or the fishing population's own perception of how it should be. Therefore, the Free Law of 1857 was a political intervention instrument for change that contributed to bring equity into the construction of sea space. The Free Law liberated the fishers from merchant control, but unfortunately, the result of the Free Law, according to Jentoft and Kristoffersen (1989), was anarchy on the fishing grounds in Lofoten.

\section{The need to limit freedom-From new regulations in Lofoten to trawl-free zones}

From the 1860s, the space issue once again became central in Norwegian fishing, not only in Lofoten, but also in several places along the coast. The attempt to abolish the spatial regulations in Finnmark to bring the regulations in accordance with the Free Law met resistance from the fishers. It turned out that the regulations under the Free Law were not sufficient to keep peace and order in the Lofoten fisheries and conflicts increased. In addition, the Norwegian authorities had to consider other political issues. Fishers were poor, independent, small-scale operators and even if the Free Law liberated them from the merchants, they still needed protection from capitalistic and largescale operators who now under the Free Law gained new opportunities. Fish merchants were involved in large-scale fishing operations. Liberated from merchants' control, the fishers now had to compete with the merchants' capital-intensive fishing operations. Jentoft and Kristoffersen (1989) wrote about the events in Trollfjord in 1890 where a steamship had closed the fjord with a net and where the small-scale fishers protested against this by attacking the steamship. This occasion created an important symbolic image of the independent small-scale fishers fighting bigger powers and showed that they were in need of protection. The 1897 law did not directly ban seine in Lofoten cod fishing, but had a section making it possible to regulate the use of seines. Nevertheless, the change the Free Law represented what was important for the design of the new regime that followed from 1897. On the other hand, some of the ordering principles from the Law of Order were reintroduced but modified to fit with the principles of equity (Prp 1896). After the Free Law, the construction of the sea as a free-for-all space has until today received strong support in Norway, in the sense that nobody can claim an exclusive, perpetual right to a certain spot at sea. However, as the following will 
illustrate, this freedom is not total, and regulations are necessary to create order and to secure equity, which has been an important concern in Norway.

Other countries in Europe had a tradition of trawling, which similar to certain types of seining, is a capital-intensive fishing method. The coastal fishers in Norway considered trawling as a capitalistic large-scale adaption that threatened the small-scale rural fishing industry (Holm 1995). A general ban on trawling came into effect in Norway in 1908. A more liberal policy was adopted by the mid-1930s when the Trawler Act allowed trawling but only by special permission with certain conditions and with a prohibition against trawl fishery in areas where the coastal fishers fished. The Trawler Act protected the coastal fishers with passive fishing gear against the industrial economy. The law limited the number of trawlers and the investment in this segment of the industry. These regulations were part of a political project to secure the well-being of the coastal fisher population. In Norway, trawlers had to comply with spatial regulations, in particular to prevent area conflicts between passive gear and trawling. These arrangements were not unilaterally directed against Norwegian trawlers, but limited the foreign trawlers fishing in Norwegian waters before the 200 Nautical Mile (NM) Exclusive Economic Zone (EEZ) was established in 1977 (Fig. 2). With the EEZ, Norway's jurisdiction expanded and the country could start to use more extensive fishery regulations. The Saltwater Fisheries Act of 3 June 1983 gave the Ministry of Fisheries a mandate to establish trawling zones and to regulate fishing in the so-called 'flexible areas'. The law maintained the ban on trawling (except shrimp, seaweed, and crayfish trawls) within territorial waters (12 NM from baselines) but allowed exceptions under certain conditions and areas specified in regulations (FOR-2004-12-22-1878). In addition, the Marine Resources Act $(\$ 20)$ can also regulate trawling according to $\mathbb{} 16$ on flexible areas. These rules make it possible to establish measures that both reduce conflicts with passive gear, protect fishing grounds, and reduce impact on the sea bottom. In addition, there are several trawl-free zones along the coast. In Northern Norway, regardless of the ban on trawling, trawlers with an obligation to land fresh fish locally can in certain periods of the year fish in specified zones between four and six NM. The regulation on fishing conduct (FOR-2004-12-22-1878) specifies a wide range of measures that are both technical and spatial where trawling is allowed or banned in certain areas. Also, other gear types are regulated through space, for example, long liners over $21.35 \mathrm{~m}$ with automatic bating must as a general rule fish outside $4 \mathrm{NM}$ and even further out in certain areas and periods, while hand baiters do not have to comply with this rule. A similar rule applies to offshore crab vessels over $21,35 \mathrm{~m}$. The spatial regulations of the trawling industry and the other regulations of effective offshore fishing vessels minimise conflicts between different gears, and as such they maintain order, but the purpose of several of them are political. The aims are to protect local fisheries, landings, and employment. Hence, these regulations are mainly interventions for equity even if today they may also contribute to conservation.

\section{The need to protect nature: Interventions for conservation and sustainability}

In the period between 1972 and 1990, an invisible revolution took place in Norwegian fisheries' management (Holm 1996, 2001). The herring stock collapse at the end of the 1960s opened both fishers' and managers' eyes to the need for more thorough management of the fisheries' resources. Epistemically, governmentality now acquired a new 
dimension, namely, that human action could have a negative effect on the natural environment. Ethically, there was a deeper concern for the consequences of human behaviour on nature. The UN Law of the Sea (UNCLOS) process that ended in 1982 with a 'constitution' of the sea changed the ocean regime from a Mare Liberum that was free for all to oceans that throughout the 1970s and 1980s became largely divided into regional seas under national jurisdictions. Thus, UNCLOS led to an increased global territorialisation of the oceans. Gradually in Norway, partly due to the experience with the herring collapse, the fishery policy shifted focus from fisher wellbeing to fish wellbeing. Fish wellbeing is a question with political dimensions, but it also rests upon technical and scientific knowledge. Consequently, scientific experts now acquired a much more prominent role in governance, both as producers of formal knowledge for governance, but also as translators of natural complexity and constructors of SG (see Fig. 1). Moreover, the need for and increasing use of formalised knowledge represented a new phase in the governmentalisation process. When scientists' stock assessments indicated a collapse of Arctic cod in 1989, all involved parties accepted that radical steps to protect the stock were necessary, but without total agreement about what to do. Based on a long tradition for collaboration, the authorities and the fishers' organisations entered into negotiations about measures, and after 1989 authorities and stakeholders have cooperated on the development of measures to conserve and protect nature and to ensure sustainability (Johnsen 2014, Jentoft and Johnsen 2015). Since 1990, the measures grew in number and comprehensiveness. The conventional fishery regulation measures in the form of output and input regulations and technical measures, which I will not mention here, are already well described in other works (Holm 2001, Hersoug 2005, Johnsen 2014, Jentoft and Johnsen 2015), but there are some more recent spatial measures that I will address. As examples, I will first briefly describe the most complex and comprehensive, namely the fjord-line system to protect coastal cod. Second, I will describe the use of flexible areas, real-time closures (RTC), and precautionary areas before I describe the spatial regulations in red king crab management. Finally, in the last part I will comment on the use of conservation and marine-protected areas (MPAs) in Norway.

\section{Coastal cod protection and the fjord-lines}

For many decades, Arctic cod (Gadus morhua) was managed as one single stock, although marine researchers have known since the 1930s that the stock consists of several components. One of these components is a variety of local, rather stationary cod populations that spawn in the many fjords in Norway. The cod fishery is quota regulated, but the quotas do not distinguish between the different components of cod. In the period of 1997 to 2003, the Institute for Marine Research in Norway found many of these populations to be very weak, and in 2004, the Ministry of Fisheries and Coastal Affairs implemented measures to protect the many populations of coastal cod. ${ }^{10}$ The aim was to rebuild the populations back to full reproductive potential (Fisheries Directorate 2016). Since 2004, coastal cod fishing is strictly regulated by the use of a specific measure called the fjord-lines, lines that are drawn along most of the coast from Stad on the West Coast of Norway to Varanger in the Northeast (FOR-2004-1222-1878) inside the baselines (Figs. 2 and 3) that define the breadth of the territorial sea. ${ }^{11}$ Within the fjord-lines there are restrictions regarding species, vessel length, and gear. Conventional vessels over $15 \mathrm{~m}$ cannot in general fish after cod within these lines, 


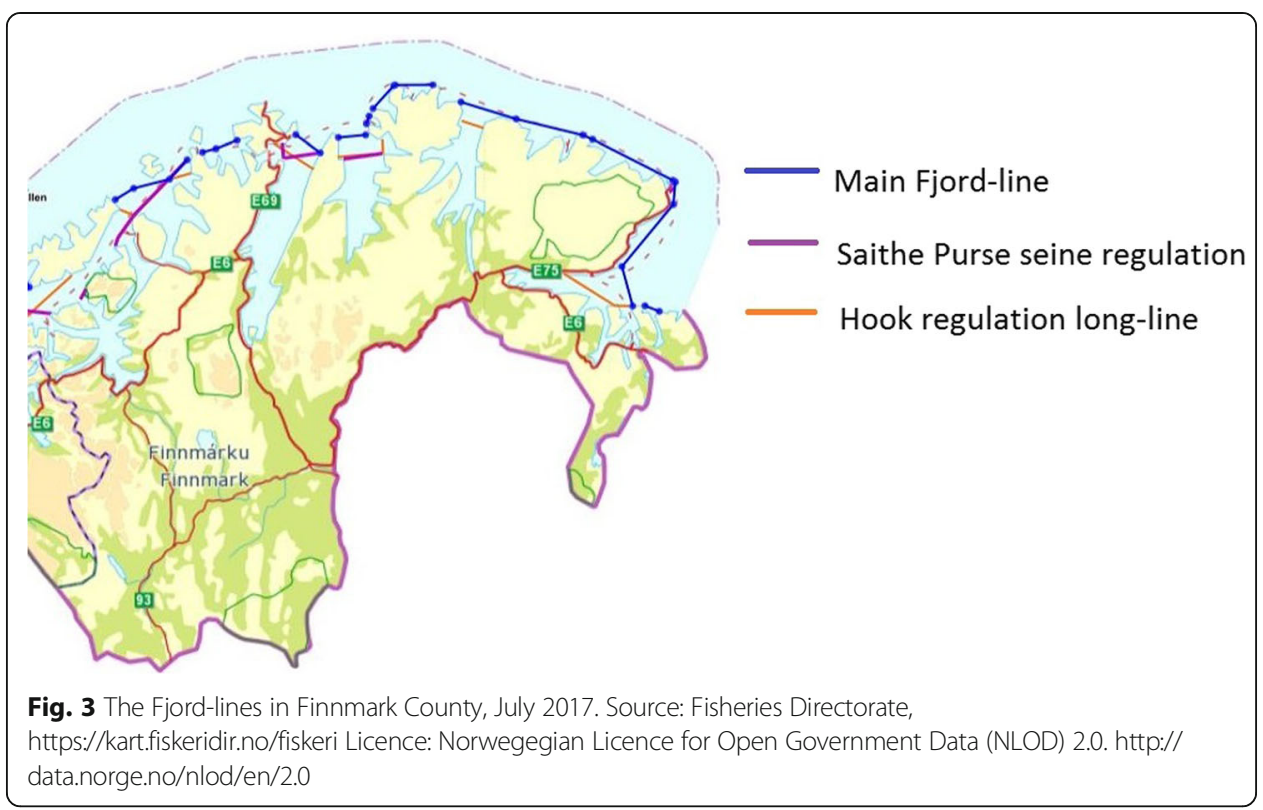

and there is a general ban on fishing for cod with Danish seine inside the fjord-lines. Shrimp trawlers that due to size and species can fish inside the fjord-lines have to use sorting devices. Small long-lining vessels can only deploy 5000 hooks pr. day inside the Fjord-lines. There can be regional and seasonal adjustments to the general rules. Vessels over $15 \mathrm{~m}$ can fish for other species like, for example, herring inside the fjordlines, but must leave the fishing ground if there is too much cod in the catches. Regardless of these regulations, conventional vessels over $21 \mathrm{~m}$ are in general advised to fish cod outside the baseline, which run outside the fjord-lines, but can still fish into the fjord-lines. Vessels over $21 \mathrm{~m}$ are not banned from fishing inside the baselines but are advised not to and can be allowed to fish inside the fjord-lines in other fisheries than after cod and saithe, where they have normally fished closer to shore. Most vessels over $21 \mathrm{~m}$ follow this advice, which illustrates a willingness to comply with regulations. A specific body, the Fjord Fisheries Board (FFB) discusses and proposes fjord-lines for the Fisheries Directorate that takes the final decision. The need to protect nature from human impact is the ethos for the specific area regulations, and their episteme rests on fishery science and coastal cod assessments. The justification for establishing the fjord-line regulation was ecological, but the regulation thus has a distribution effect, favouring small-scale vessels on the near shore fishing grounds. Many of the proposals from the FFB have been perceived as quite controversial, because the proposed lines by many fishers are regarded as more politically than ecologically based. ${ }^{12}$ On the other side, the space in many fjords may already have been regulated under local customary regimes that the FFB now has to consider. Nevertheless, the fjord-line regulations are important for the small-scale Sami fisheries in particular, and their function and content will be subject to continued negotiations (Jentoft and Søreng 2017). Following on from the discussion about them in official documents, newspapers, and minutes from fisher organisations meetings, these regulations are in addition to the ecological foundation, also perceived by some fishers as moving towards interventions for equity. 
The need for flexibility: Flexible areas, real-time closures (RTC), and precautionary areas Norwegian fisheries are dynamic and migratory. Even if they are rather targeted and organised as such, a mix of species and year classes of fish may be abundant on the same fishing grounds. Moreover, sometimes species targeted by one vessel group may be abundant on fishing grounds used by another. Such challenges are met partly through flexible spatial and temporal measures like flexible areas, real-time closures (RTCs), and precautionary areas when it is regarded as necessary (Sections 16 and 20 Marine Resources Act, FOR-2004-12-22-1878). The flexible areas regulate fishing in specific periods through restrictions or bans on fishing with certain gear types in all or parts of an area. Flexible areas regulations can also limit the number of fishing vessels that can fish in a certain period. Establishment of flexible areas can be based on ecology, effectivity, and equity considerations. RTCs, on the other hand, are mainly used to close fishing grounds on the basis of monitoring juveniles or bycatch in certain fisheries. In Norway, this came into use after the cod crisis, where the Fisheries Directorate established a department for monitoring of fishing grounds to control the catch of juvenile cod in the shrimp fishery. RTCs are implemented to reduce discards in the North Sea fisheries. The main purpose of the RTC is to protect the fry and small fish by closing areas of high impact. It is accordingly an ecologically justified scheme. In flexible areas, certain fisheries can be banned or regulated for a temporary period, while RTCs are used to close and open areas that are more continually monitored. Control of compliance with both flexible areas and RTC has become easier due to the use of satellite-based vessel monitoring systems (VMS) and electronic catch. Electronic reporting is mandatory for all commercial fishing vessels while VMS is mandatory for fishing vessels over $15 \mathrm{~m}$. Nowadays, there is continuous monitoring of fishing vessels over $15 \mathrm{~m}$ in Norwegian waters.

Precautionary areas are areas where the Coast Guard or the Fisheries Directorate, on the basis of sampling, warn the fishers that there may be a high risk of breaking the rules. Fishing is legal in precautionary areas, and they are, as such, not regulations but indicate a recommendation for responsible conduct. The fishers may expect active monitoring and control, and a warning issued about a precautionary area can be followed by a closure for fishing in the area. The purpose is mainly to protect juveniles or to avoid bycatch, and the precautionary area establishment is ecologically justified. The administrative precautionary purpose is clear: the authorities are obliged to inform citizens so they can avoid violations and conflict with regulations. The consequence is that fishers in such areas are responsible for executing self-control. Because of the warning in advance, they cannot claim to have been in good faith if they violate the rules.

\section{Space for extinction and management-King crab fishery regulations}

In the 1960s, the Soviet Union released red king crab (Paralithodes camtschaticus) from the Pacific on the east coast close to Murmansk. From 1992, a large number of crab came into Norwegian waters. The crab invasion partly destroyed the traditional fisheries in Eastern Finnmark and had a severe impact on the local ecology. The stock grew to a commercial size, and in 2002 a commercial fishery for king crab opened, and a spatial management regime was established. First, the regime aimed to facilitate a commercially profitable fishery for those who were most impacted by the invasion, and second, the regime aimed to prevent the crab spreading further to the west. The spatial 
regulations for the crab fishery is part of a more detailed regime, but here I focus on the spatial arrangements. The spatial regulation has two components: a management zone between 26 degrees east and 71 degrees 30 min north, with the border to the Russian EEZ as the eastern limit (Fig. 2). In the management zone, the king crab is managed as a commercial stock to produce a yield. West and north of this zone it is a free open access fishery for king crab. The fishery outside the management zone is an extinction fishery with the aim to minimise the size and abundance of the stock. This free fishery aims to prevent the crab invasion continuing west of 26 degrees east. The number of vessels participating in the free fishery outside the zone has declined during the last years, partly due to lower catch rates, but also stricter rules. From 2014, VMS was mandatory for all vessels in the crab fishery, which makes it difficult to fish inside the management zone and report the catch in the open fishery area. In the management zone, there is a quota-regulated fishery for vessels under $21 \mathrm{~m}$. Originally, access to the fishery required special permits. Nowadays all vessels over $6 \mathrm{~m}$ and under $15 \mathrm{~m}$ registered in one of the municipalities adjacent to the zone with an owner registered and settled in the area have access to the fishery and can fish a small quota. Thus, the smallest vessels have a territorial 'right' to access the resource. The vessel owner has to be a skipper under the fishery. Vessels between $15 \mathrm{~m}$ and $21 \mathrm{~m}$ need a special permit to participate. In 2014, 551 vessels participated in the quota-regulated fishery. The main arguments for the spatial arrangements are partly ecological-the need to limit the spread of the crab west of 28 degrees east-but also to maintain a sustainable fishery for those who are most affected by the king crab invasion. In addition, since crab is a valuable resource, the regulations shall also benefit the vessels between 15 and $21 \mathrm{~m}$ that contribute the most to local activities and employment by also exploiting other species (Meld. St. 17 2014-2015).

\section{Biodiversity conservation-Marine protected areas (MPAs)}

The broader international marine governance discourse that focusses on biodiversity affects Norwegian marine governance. A concern for the protection of single stocks and conservation of habitats and ecosystem is expressed in the Marine Resources Act report (NOU 2005). Biodiversity conservation objectives are present in discussions about marine conservation in general and have been set forth in proposals for establishment of Marine Protected Areas (MPAs) in Norway. ${ }^{13}$ A new section about MPAs is included in the Marine Resources Act (Section 19). The fishing impact on deep-water coral reefs has over time become a concern. Since 2004, the fisheries authorities have protected nine deep-water coral reefs from fishing. ${ }^{14}$ In addition, the Ministry of Climate and Environment has coordinated the development of a plan for the protection of unique marine nature, and a process of protecting areas in coastal waters has started. So far, the MPAs in Norway have rather specific purposes, either coral reef protection, protection of a unique type of nature, or to establish reserves for specific species, normally lobster. MPAs are primarily justified by ecological and conservationist arguments. The MPA plan for Norway has defined 36 potential MPAs, and the process to establish them has started for five of them. Three MPAs are already established.

The Marine Resources Act (2008) authorises the option for local authorities (municipalities) to create protection areas, where the Fisheries Directorate or the relevant ministry approves the local arrangement through a legally binding regulation. Such 
examples are the zoning in the Tvedestrand municipality and establishment of a protection area in the Lindesnes municipality. Researchers played an important role as agents for these processes (Celius 2014, Espeland et al. 2016). ${ }^{15}$

\section{Establishing a typology for spatial regulations in Norway}

Based on deduction and interpretation of how the purposes and objectives connect to the development of general marine resource governance objectives in Norway, the rhetoric in the documents I have referred to can be characterised as rhetoric about conservation, effectivity, and equity. Section 7 in the Marine Resources Act (2008) translates these rhetoric into objectives under the heading: 'Principle for management of wild living marine resources and fundamental considerations'. Conservation is about protection of resources, habitat, and environment and is mentioned in the Section 7 introduction and in points (a), (b), and (f). It effectivity addresses both economic efficiency and order, so the fishers can fish without problems and conflicts and allows control to be effective (Marine Resources Act [2008], Section 7, points (c) and (e)). Equity is about legitimacy and fairness in terms of access to and allocation of resources as well as shares of the income (Marine Resources Act Section 7, point (d)). The equity dimension includes a special concern for the Sami fisheries (Marine Resources Act [2008], Section 7 point (g)). The Marine Resources Act encompasses all the marine resource oriented regulations, and the rhetoric reflects the ethos both for former regulations and for the regulations in use in Norway today.

Based on this, I divide the spatial regulations in Norway into three categories: Interventions for Effectivity, Interventions for Equity and Fairness and Interventions for Conservation and Sustainability. The categories are not exclusive; regulations may have more than one purpose, but the main argument for establishing them will belong to one of these types. The two first categories have a long history dating back to the eighteenth century, while the regulations for conservation have a more recent origin. The thirteen spatial 'instruments' that I presented in the previous section article fall under one, two, or all three categories. As both Table 1 and the description illustrate, there has been a development over time from simple to more complex objectives. Of the regulations presented in Table 1, six have effectivity as the only or the main objective, six are linked to equity, and eight are directed towards conservation. Under these thirteen instruments, there are several other more specific regulations that may vary in details but with their main objective related to at least one of the categories (see Table 1).

The three types of interventions have different ethos and episteme. The ethos for Interventions for Effectivity is the effective use of resources based on economic and technical calculations as the episteme; waste of resources through ineffective exploitation is unethical. Order on the fishing grounds was seen as a main element for creating effectivity. Interventions for Equity and Fairness has equity and fairness as aim and builds on a belief that all humans shall have equal rights and opportunities. The episteme is more about clarifying values, needs, and rights. Protection of coastal and small-scale fisheries from fierce competition from large-scale operations like trawling and mechanised longlining has been and is an important aspect in these interventions. Interventions for Conservation and Sustainability regard humans as a threat to nature and regards it as immoral not to regulate human impact. The episteme is the scientific representations 
Table 1 A selection of area regulations in Norway 1800-2016

\begin{tabular}{|c|c|c|c|c|}
\hline & & $\begin{array}{l}\text { Intervention for } \\
\text { Effectivity (IE) }\end{array}$ & $\begin{array}{l}\text { Intervention for Equity } \\
\text { and Fairness (IF) }\end{array}$ & $\begin{array}{l}\text { Intervention for } \\
\text { Conservation and } \\
\text { Sustainability (IC) }\end{array}$ \\
\hline 1 & Law of Order (Lofoten) 1816 & $x$ & & \\
\hline 2 & The Free Law (Lofoten) 1857 & & $x$ & \\
\hline 3 & The Lofoten Law 1897 & $x$ & $x$ & \\
\hline 4 & Local committees (Lofoten and other Areas) & $x$ & & \\
\hline 5 & Local regulations & $x$ & & $x$ \\
\hline 6 & $\begin{array}{l}\text { Spatial regulations for Trawlers and Long } \\
\text { liners over } 21.35 \mathrm{~m}\end{array}$ & & $x$ & \\
\hline 7 & Fjord Lines & & $x$ & $x$ \\
\hline 8 & Flexible Areas & $x$ & $x$ & $x$ \\
\hline 9 & Real Time Closures & & & $x$ \\
\hline 10 & Precautionary Areas & & & $x$ \\
\hline 11 & Marine Protected Areas & & & $x$ \\
\hline 12 & Local Protection Zones & & & $x$ \\
\hline 13 & King Crab regulation & $x$ & $x$ & $x$ \\
\hline
\end{tabular}

of nature, and these interventions are based on advice from expertise, for example, about the need for protection of areas and on monitoring for real-time closures. Table 1 shows how spatial regulations can be categorised based on the typology.

Even if the purpose behind the Interventions for Effectivity and the Interventions for Equity and Fairness have been or are different, they have in common that they direct behaviour in relation to societal objectives. They mirror the rationalities and power relations that dominated in society when they were established; the concerns behind them were human well-being and societal development. The Lofoten Laws framed the system-to-be governed as a social network, and governing, governance, and governmentality were about arrangements that protected or changed the social order. Even today, these kinds of arrangements still have a largely political character. Social and political processes can change them, either through negotiations, use of power, or through influence and organisation. As I mention below, this happened after 1990 when these interventions received a new ethos. This happened because after the Arctic cod stock collapse scientific experts and politics completed the reconstruction of the fishery system-to-be-governed from a social to a socio-ecological system. This reconstruction process took place over a long period (Holm 2001), but was somehow completed when concerns for nature replaced concerns for humans as the most prominent in governance. The Interventions for Conservation and Sustainability are justified by ecological arguments and sprung out of this reconstruction process. These interventions depend on input from ecological or biological expertise. The use of these interventions has contributed to expanding Norwegian thinking about what we govern. While Interventions for Effectivity and Interventions for Equity and Fairness mainly address human-human or human-society relations, the Interventions for Conservation and Sustainability address human-nature relations. With the reconstruction of the system-to-be-governed from a human system to a coupled socio-ecological system, with acceptance of scientific models of fish stocks and ecosystems as true representations of nature, the notion of what to govern and how to govern changed. The 
perception of nature-human relations changed. The new conservation and sustainability interventions were required, but even the former regulations of the Interventions for Effectivity or Interventions for Equity and Fairness became loaded with the new conservation and sustainability ethos.

\section{Discussion-The production of governmentality and governability}

Spatial regulations do not only regulate behaviour, but they change perceptions, attitudes, and meanings about the sea space and its inhabitants. The Free Law for example led to a chaotic situation; still, it manifested equity as a central element in Norwegian fisheries governance. It had an impact on the coproduction of networks of meanings, understandings, and concepts shared by the actors in the governing system/system-tobe-governed complex. Therefore, even if regulations fail to produce the expected instrumental outcome in the short run, they may contribute to governmentalisation. Over time, governmentalisation is an 'invisible revolution' like Holm (2001) described in his study of institutional changes in Norwegian fisheries. Governmentalisation is about development of new networks of meanings, based on the translation of events and experiences into ideas and storylines that explain, structure, and institutionalise the world (Sønvisen 2013). These new networks of meanings direct new actions. From this perspective, experiences with open access, the need for regulation of order, the stories about resource collapse, regulations for change, protection of areas, and the impacts of the Gordon-Schaefer model on fisheries management, transferable quota arrangements, and trawl-free zones are elements in a construction of a shared contextual framework that makes the art of governing possible. In this respect, the processes of cyborgisation in the form of structuring, ordering, and organising fishing practices as actionfeedback-response both inside and between systemic organised bodies, also fits into the process of governmentalisation (Bavington 2009; Johnsen et al., 2009a, b).

On the other hand, the fishers are not faceless victims. As Jentoft and Kristoffersen (1989), Jentoft (2007), Johnsen (2014), and Jentoft and Johnsen (2015) describe, development of governability cannot be understood without the participation of the fishers. In the Norwegian context, the fishers' response to governing interventions and their ability to self-govern affects the formation of the governing system and the system-tobe-governed. Moreover, we cannot understand governability without the actions of the scientists who model different elements in the system-to-be-governed and suggest causes and effects. Their input is important for formation of objectives and intervention design. Finally, we need to know about the governing system and system-to-begoverned responses to scientists' input. In this paper, I have described how spatial regulation procedures and instruments aim to direct human behaviour in relation to effectivity, equity, and conservation. If governmentality is the art of governing, and the concept includes mentalities, rationalities, and techniques for governing (Lemke 2001, Mayhew 2009), governmentality depends on shared understandings between the actors that together construct or accept the construction of the governing system/system-tobe-governed. Mentality, rationality, strategies, laws, rules, regulations, and the ability to adapt and change will be part of the governing system and the system-to-be-governed. Jentoft and Johnsen (2015) call the ability to adapt for change adaptamentality, and it is an important part of governmentality as the governed have a voice and the governors and their allies no longer exclusively control authorised knowledge. Interventions for 
Effectivity, Interventions for Equity and Fairness, and Interventions for Conservation and Sustainability should perform different rationalities and serve different purposes. The rationality they convey may become symbolic signposts for successful governance while their invisible contribution may be more important. The Law of Order's success was the institution of spatial organisation it created, not the inequality it conveyed. The success of the fjord-lines may not only be measured in relation to healthy coastal cod populations, but to a division of space that reserves fishing near shore for smaller boats. Even if some of the instruments like the RTC, flexible areas, and precautionary areas are more technical means that are used in pragmatic ways to meet particular challenges, they contribute to disciplining the fishers and are important for governmaentalisation. The spatial interventions are not neutral regulatory instruments; they are performative agents that contain a variety of potential images, modelled relationships, ideology, and drivers for change that make them usable for several purposes (Johnsen 2014). Even if the Norwegian system is stable, it is not fixed. It changes incrementally and somewhat invisibly over time, but with some major principles (democracy, legality, equality, transparency, and effectivity) intact. Adjusting the governing system/systemto-be-governed means adjusting to new images, models, or metaphors (Ostrom 1990), but if a radical adjustment is to take place, the context must probably change radically as it did with the herring collapse in the 1960s or on 18 April 1989 when the open cod fishery closed in Norway. Both these events led to ecology becoming part of the governance context. This change cleared the way for the use of new spatial tools, like RTCs, fjord-lines, and area or habitat protection. In addition, former arrangements like trawl-free zones were refuelled with ecological arguments and can now be used and developed for biodiversity conservation. All the regulations that are in use today, even if their origin was decades ago, are affected by the more general concern for biodiversity and conservation. Hence, except for the rules of order on specific fishing grounds that the fishers negotiate between themselves, all the other regulations are part of a regime of practices to achieve sustainability in the long term (Marine Resources Act, Section 7).

A 'third-order' cybernetic approach (Geyer and van der Zouven, 1991, Rhodes 1996), where the governing system/system-to-be-governed and the tools develop in concert, sees governance as evolving relations, not as fixed actors or systems. In this perspective, Fig. 1 does not depict a stable governing structure, but the flow of interests, actions, and information. In such a perspective governability cannot depend on how well the diverse management instruments (like closed areas) fit to a variety of social, physical, and natural processes, but on how well these devices convey information and actions that produce and stabilise a governing system/system-to-be-governed. A good example is Johnson and Pálsson's (2015) study of fisheries on Lake Winnipeg where an individual transferable quota (ITQ) system in a specific institutional setting seems to have enhanced governability, because the stakeholders and governors perceive them as functional, despite the problems they also create. In this case, the ITQs translate governmentality into governability. Another example is Høst's (2015) analysis of the use of market mechanisms in Denmark where the conclusion may be that too little effort is invested in trying to understand how management tools change the world. The tools make the systems governable, but the outcome may be unexpected. The Interventions for Effectivity, Interventions for Equity and Fairness, and Interventions for 
Conservation and Sustainability translate the sea into spaces for specific behaviours that allow for governing and to-be-governed. An evolving acceptance for a belief in governing and the use of concepts, methods, and instruments is exactly what governmentality is about. The outcome of this governmentalisation is governability. Hence, governability is the effect of both governing and being-governed processes. Governability depends on governmentality, but governmentalisation and governmentality depend on consensus about the governable objects, the subjects-to-be-governed, and the use of interventions. Thus, governability is not unveiled through an analysis of inherent and constructed properties, but something that grows out of the use of governing instruments, systems design adaption, and learning. We make the world governable by governing (Johnsen 2014, Jentoft and Johnsen 2015).

All regulations do more than just regulate. The regulatory instruments are in fact performative (Steinberg 2001, Callon et al., 2007, Holm and Nielsen 2007, Høst 2015). They are political tools. To govern the sea implies that constructions, practices, and enactments have to be controlled and directed, but we must acknowledge that we use performative interventions and instruments that convey several objectives, meanings, norms, and directives for practices for how the world should be. When the instruments direct people's behaviour, people also start to act in new ways that create new realities and that in turn may require new governing interventions.

In Norway, the governance system copes with the need for complicated technical regulations, with more self- regulation (Johnsen et al. 2009b, Johnsen et al., 2009b, Johnsen 2014). To detail-regulate gear rigging and vessel parameters requires a capacity to control. Hence, the authorities leave technical decisions to an increasing extent to boat owners. Compliance with the spatial regulations seems to be high in Norway (Additional file 1: Box S1). With more self-regulation, spatial measures, which are quite simple to enforce with new technology, may increase in importance in the future. VMS tracking is already in use in Norway, and in some European fisheries there are trials with video recordings of the fishing operations. Such instruments are easy to combine with the use of simple spatial measures.

\section{Conclusion-Spatial regulations for policy and as policy}

The spatial interventions may not always produce what they are anticipated or expected to do; still they change the world. They also establish new relations that in the next round are necessary to govern. The interventions presented in the left part of Fig. 1 are therefore not neutral tools taken from a neutral toolbox that aim only towards regulating specific behaviour. As I have described, when the technologies of power (like modelling and mapping of spatial and ecosystem properties) related to the Interventions for Effectivity, the Interventions for Equity and Fairness and the Interventions for Conservation and Sustainability are set in motion, they contribute to configuring and reconfiguring the relationships of the governing system and the system-to-be-governed (Johnsen et al. 2009b, Johnsen 2014, Frangoudes and Garineaud 2015). The Law of Order did not only create order, it protected society, class structure, power, and property. The Free Law reintroduced freedom and equity. The fjord-lines protect coastal cod, but they also protect small-scale fjord fishers from competition and create order near shore. The interventions are performative tools that impose policy and have comprehensive societal effects. The quota regime cannot solve problems of order or 
regulate behaviour and power on the fishing ground. The spatial regulations in their various forms fill this purpose. They are part of the larger resource governance regime, and they meet concerns that other elements in the regime cannot handle. Therefore, the story about spatial regulations in Norway is not only about regulation for achievement of political objectives but also about regulations as policy. The interventions are not primarily technical: they are political. Hence, the interventions are engineering tools, used to engineer the world so it becomes governable. Governability then is not a capacity and a quality that sits in the governing system or a property of the system-tobe-governed, but the outcome of the construction process that construct both a governing system and objects 'to-be-governed'. Governability is a capacity to create the belief in images, models, and interventions that we think may lead towards the wanted objectives. Therefore, this story about spatial management is all about how power comes into existence, how tools like Interventions for Effectivity give power to some and not to others, how Interventions for Equity and Fairness can alter power relations, and how Interventions for Conservation and Sustainability can move power from social and political processes to experts. The story I have told is about how we politicise and governmentalise the sea and how we use the tools to construct the sea space to trigger societal effects. It is evident from the instruments I have studied that there will always be politics involved. There are no pure technical regulation tools. The key to understand the politicised sea is through examination of the processes and tools to identify what assumptions and objectives they come with and how they lead to governmentalisation that produces governability. In the future, climate-change science may very well contribute to new expansions and constructions and introduce new relations to govern. On the other hand, other narratives may become important, this we cannot know; but insight into the processes will help us understand what is happening.

By studying what happens in the fisheries, we can learn something about governance, governability, and governmentality that can be useful in other parts of society. Good governance requires that we understand what the management instruments do, and therefore these instruments must be scrutinised so we become aware of the wider effects, benefits, and risks connected to them. We need to ask why we want to govern, if we want to be governed, and how we will be governed. By asking these questions, we become aware of how governance works and we become reflexive about the processes that turn us into governable citizens.

\section{Endnotes}

${ }^{1}$ Coastal Zone planning in Norway is not included in this paper, because it has its own specific history, legal framework, and organisation (see Johnsen and Hersoug 2014).

${ }^{2}$ I use the term 'system' in this article, but see systems as outcomes. A system is a specific configuration of networks of relations, actors, actions, and procedures defined at a certain moment.

${ }^{3}$ In the figure, 'management' denotes the targeted, formal interventions to regulate specific issues like quotas, impact by certain gear, or use of sea space. Hence, management is a sub-category under the broader term 'governance'.

${ }^{4}$ The concept cyb-org and cyborgisation conceptualise the cybernetic organisation. A cyb-org is cybernetically organised but does not have the radical interface between body and technology as a cyborg has. 
${ }^{5}$ The law process in Norway is described in detail on the Norwegian Parliament Web Page: https://www.stortinget.no/en/In-English/About-the-Storting/Legislation/. Accessed 7 Sept 2017. All the documents and the debate about the Marine Resources Act can be accessed here: https://www.stortinget.no/no/Saker-og-publikasjoner/Saker/Sak/?p=38917. Accessed 7 Sept 2017. An English translation of the Marine Resources Act is available here: https://www.regjeringen.no/globalassets/upload/FKD/ Vedlegg/Diverse/2010/MarineResourcesAct.pdf. Accessed 7 Sept 2017.

${ }^{6}$ Chapter 8.4 in the Marine Resources Act report (NOU 2005) is about spatial regulation of fishing.

${ }^{7}$ Three main sources are used: (a) Proposition to the Parliament for the 1857 Law (Prp 1857): O. No. 2. Angaaende naadigst Proposition til Norges Riges Storthing betræffende Udfærdigelsen af en Lov om Torskefiskeriet i Nordlands Amt og Senjens og Tromsø Fogderi. https://www.stortinget.no/no/Saker-og-publikasjoner/Stortingsforhandlinger/ Lesevisning/?p=1857\&paid=4\&wid=a\&psid=DIVL59\&pgid=a_0047\&s=True. Accessed 7 Sept 2017. The proposition sums up the situation and the rationale behind the Law of Order; (b) Proposition to the Parliament for the 1897 Law (Prp 1896): Oth. Prp. No. 24. (1896.) Om Udfærdigelse af en Lov angaaende Fiskerier i Nordlands og Tromsø Amter. https://www.stortinget.no/no/Saker-og-publikasjoner/Stortingsforhandlinger/Lesevisning/?p=1896\&paid=3\&wid=c\&psid=DIVL64\&pgid=c_0007. Accessed 7 Sept 2017.

${ }^{8}$ In 1989, Jentoft and Kristoffersen published a study of the spatial regulations in Lofoten as a successful co-management system. Their article is an important source for the description of the Law of Order and the Free Law in this article. I have not been able to find the propositions for the 1816 Law; therefore, the description of this law is based on Prp 1857 and Jentoft and Kristoffersen (1989).

${ }^{9}$ Danish seine is a seine net hauled from a boat along the bottom. The method has similarities with bottom trawling in terms of impact.

${ }^{10} \mathrm{http} / / /$ www.imr.no/filarkiv/2016/05/torsk-nord_62.pdf/nb-no. Accessed 7 Sept 2017.

${ }^{11}$ According to Article 5 and 7 in UNCLOS, the normal baseline for measuring the breadth of the territorial sea is: 'the low-water line along the coast as marked on largescale charts officially recognized by the coastal State. //In localities where the coastline is deeply indented and cut into, or if there is a fringe of islands along the coast in its immediate vicinity, the method of straight baselines joining appropriate points may be employed in drawing the baseline from which the breadth of the territorial sea is measured.' Norway applies the principle of straight baselines.

${ }^{12}$ The future construction of the Arctic and coastal cod stock may influence the future of the fjord-line arrangements.

${ }^{13}$ See web page for marine conservation in Norway: http://www.miljodirektoratet.no/ no/Tema/Verneomrader/Marin-verneplan/. Accessed 7 Sept 2017.

${ }^{14} \mathrm{http}$ ://www.fiskeridir.no/Yrkesfiske/Areal-og-miljoe/Saarbare-omraader-koraller/Vernav-korallrev. Accessed 7 Sept 2017. https://lovdata.no/dokument/SF/forskrift/2004-12-221878/KAPITTEL_15\#\$66. Accessed 7 Sept 2017.

${ }^{15}$ Interest in expanding oil and gas operations further north and into Arctic waters led to a process of developing management plans for the Barents Sea and Lofoten area. There are no measures related to these plans; today they are political guidelines for the sector authorities, but their importance may increase in the future (Johnsen and Hersoug 2014). 


\section{Additional file}

Additional file 1: Box S1. Compliance with spatial regulations in Norway. (DOCX 16 kb)

\section{Acknowledgements}

Research assistant Trine Holm Larsen helped me to systematise and analyse the many different spatial regulations in Norway. Thanks to Charles Mather, Arthi Stridar, Johnny Stevens, Signe Sønvisen, and the people who commented on my paper and presentation at the Governmentality Panel at the Mare Conference in 2015. Thanks also to the two anonymous reviewers and the editors of Mast for their useful comments. I would also like to thank Proof-Reading Services for copy-editing.

\section{Funding}

This article is based on data from the project Konsekvenser av. friere redskapsvalg i norske fiskerier, project number 900535, funded by The Norwegian Seafood Research Fund (FHF). The Norwegian College of Fishery Science at UiT, The Arctic University of Norway has supported the writing of this article. The publication charges for this article have been funded by a grant from the publication fund of UiT, The Arctic University of Norway.

\section{Availability of data and materials}

The main material is referred to and presented in the literature list or the endnotes. An excel sheet with more detailed information about the spatial regulations will be provided upon request.

\section{Ethics approval and consent to participate}

The article is based on document studies. The references made to fieldwork and observations refer to observations and interviews made under full consent from the informants. No personal information is used or presented in this article. The author has followed the Guidelines for Research Ethics in the Social Sciences, Humanities, Law, and Theology.

\section{Consent for publication}

Not relevant.

\section{Competing interests}

The author declares that he/she has no competing interests.

\section{Publisher's Note}

Springer Nature remains neutral with regard to jurisdictional claims in published maps and institutional affiliations.

Received: 7 March 2017 Accepted: 30 August 2017

Published online: 30 October 2017

\section{References}

Anon. 2008. Innst. O. nr. 45 (2007-2008). Innstilling fra næringskomiteen om lov om forvaltning av viltlevande marine ressursar (havressurslova) [Recommendation to the Parliament from the Parliament Committee for industry and trade about the marine resources law]. https://www.stortinget.no/no/Saker-og-publikasjoner/Publikasjoner/ Innstillinger/Odelstinget/2007-2008/inno-200708-045/. Norwegian Parliament. Accessed 7 Sept 2017.

Arnason, Ragnar. 2008. Iceland's ITQ system creates new wealth. The Electronic Journal of Sustainable Development 1 (2): 35-41.

Ban, Natalie C., lain R. Caldwell, Thomas L. Green, Siân K. Morgan, Kerrie O'Donnell, and Jennifer C. Selgrath. 2009. Diverse fisheries require diverse solutions. Science 323 (5912): 338-339.

Bavington, Dean. 2009. Managing to endanger: Creating manageable cod fisheries in Newfoundland \& Labrador, Canada. Maritime Studies 7 (2): 99-119.

Berkes, Fikret. 2010. Shifting perspectives on resource management: Resilience and the reconceptualisation of 'natural resources' and 'management'. Maritime Studies 9 (1): 13-40.

Caddy, John F., and Kevern L. Cochrane. 2001. A review of fisheries management past and present and some future perspectives for the third millennium. Ocean \& Coastal Management 44 (9-10): 653-682.

Callon, Michel, Yuval Millo, and Fabian Muniesa, eds. 2007. Market devices. Malden, Oxford and Victoria: Blackwell Publishing.

Celius, Håkon. 2014. Forvaltning av marine ressurser i kystsonen i Tvedestrand. En utforskende studie av aktører og berørte parters involvering i prosesser mot et lokalt tilpasset forvaltningsregime (Management of marine resources in Tvedestand's coastal zone). Master thesis in Fisheries and Aquaculture, Norwegian College of Fishery Science, UIT-The Arctic University of Norway.

Chuenpagdee, Ratana, and Svein Jentoft. 2015. Exploring challenges in small-scale fisheries governance. In Interactive governance for small-scale fisheries: Global reflections, ed. Svein Jentoft and Ratana Chuenpagdee, 3-16. Cham: Springer International Publishing.

Dean, Mitchell. 2010. Governmentality. Power and rule in modern society. 2nd ed. Los Angeles: Sage.

Espeland, Sigurd H., Alf R. Kleiven, Even Moland, Portia Joy Nillos Kleiven, Kim Halvorsen, Torjan Bodvin, Esben Moland Olsen, and Jan Atle Knutsen. 2016. Aktiv forvaltning av marine ressurser - Lokalt tilpasset forvaltning. [Active management of marine resources- Local adaptive management] Tvedestrand. Sluttrapport. Rapport nr. 40-2016. Bergen: Institute of Marine Research.

Fisheries Directorate. 2016. Høring Av forslag vedrørende fjordlinjer og redskapsbegrensinger i kystnært fiske. [Public hearing of proposal for fjord-lines and technical regulations in coastal fisheries]. Fisheries directorate 15.04.2016. 
FOR-2004-12-22-1878. Forskrift om utøvelse av fisket i sjøen [Regulation of Professional Fishing Conduct in the Sea in Norway]. Oslo: Ministry of Industry and Fisheries. Lovdata. Accessed 13 Feb 2017.

Foucault, Michel. 1978a. Security, territory, population. In Lectures at the college de France 1977-1978, ed. Michel Sennellart, Francois Ewald, and Allessandro Fontana. Basingstoke: Palgrave Macmillan.

Foucault, Michel. 1978b. Lecture 15 March. In Security, territory, population lectures at the college de France 1977-1978, ed. Michel Sennellart, Francois Ewald, and Allessandro Fontana, 255-283. Basingstoke: Palgrave Macmillan.

Foucault, Michel. 1978c. Lecture 1 February. In Security, territory, population lectures at the college de France 1977-1978, ed. Michel Sennellart, Francois Ewald, and Allessandro Fontana, 87-114. Basingstoke: Palgrave Macmillan.

Foucault, Michel. 1978d. Lecture 11 January. In Security, territory, population lectures at the college de France 1977-1978, ed. Michel Sennellart, Francois Ewald, and Allessandro Fontana, 1-27. Basingstoke: Palgrave Macmillan.

Frangoudes, Katia, and Clément Garineaud. 2015. Governability of kelp forest small-scale harvesting in Iroise Sea, France. In Interactive governance for small-scale fisheries: Global reflections, ed. Svein Jentoft and Ratana Chuenpagdee, 101-115. Cham: Springer International Publishing.

Geyer, Felix, and Johannes van der Zouven. 1991. Cybernetics and social science: Theories and research in sociocybernetics. Kybernetes 20 (6): 81-92.

Hannesson, R. 2004. The privatization of the oceans. Cambridge: MIT Press.

Hansen, Lars Ivar, and Bjørnar Olsen. 2004. Samenes historie. Fram til 1750. Sami history up to 1750. Oslo: Cappelen.

Hardin, Garret. 1968. The tragedy of the commons. Science 162: 1243-1248.

Hersoug, Bjørn. 2005. Closing the commons. Eburon: Norwegian fisheries from open access to private property. Delft.

Holm, Petter. 1995. The dynamics of institutionalisation: Transformation processes in Norwegian fisheries. Administrative Science Quarterly 40 (3): 398-422.

Holm, Petter. 1996. Fisheries management and the domestication of nature. Sociologia Ruralis 36 (2): 177-188.

Holm, Petter. 2001. The invisible revolution. The construction of institutional change in the fisheries. Dr.philos-thesis, Norwegian College of Fishery Science, University of Tromsø.

Holm, Petter, and Kåre Nolde Nielsen. 2007. Framing fish, making markets: The construction of individual transferable quotas (ITQs). In In market devices, ed. Michel Callon, Yuval Millo, and Fabian Muniesa, 173-195. Malden: Oxford and Victoria: Blackwell Publishing.

Hutchinson, Alan. 2014. Disse Rigers Coloni. [About Finnmark's in Norway's fishery and coastal history]. In Norges fiskeri- og kysthistorie: Fangstmenn, fiskerbønder og værfolk, ed. Alf Ragnar Nielssen, Nils Kolle, and Aslak Kristiansen, 449-471. Bergen: Fagbokforlaget.

Høst, Jeppe. 2015. Governing through markets: Societal objectives, private property rights and small-scale fisheries in Denmark. In Interactive governance for small-scale fisheries: Global reflections, ed. Svein Jentoft and Ratana Chuenpagdee, 319-336. Cham: Springer International Publishing.

Jentoft, Svein. 2007. Limits of governability: Institutional implications for fisheries and coastal governance. Marine Policy 31 (4): 360-370. https://doi.org/10.1016/j.marpol.2006.11.003.

Jentoft, Svein, and Ratana Chuenpagdee. 2015a. Assessing governability of small-scale fisheries. In Interactive governance for small-scale fisheries: Global reflections, ed. Svein Jentoft and Ratana Chuenpagdee, 17-35. Cham: Springer International Publishing.

Jentoft, Svein, and Ratana Chuenpagdee. 2015b. Enhancing the governability of small-scale fisheries through interactive governance. In Interactive governance for small-scale fisheries: Global reflections, ed. Svein Jentoft and Ratana Chuenpagdee, 727-747. Cham: Springer International Publishing.

Jentoft, Svein, and Ratana Chuenpagdee, eds. 2015c. Interactive governance for small-scale fisheries: Global reflections. Cham: Springer International Publishing.

Jentoft, Svein, and Jahn Petter Johnsen. 2015. The dynamics of small-scale fisheries in Norway: From adaptamentality to governability. In Interactive governance for small-scale fisheries. Global reflections, ed. Svein Jentoft and Ratana Chuenpagdee, 705-723. Cham: Springer International Publishing.

Jentoft, Svein, and Trond Kristoffersen. 1989. Fishermen's Co-management: The case of the Lofoten fishery. Human Organization 84 (4): 355-365.

Jentoft, Svein, Bonnie McCay, and Douglas C. Wilson. 1998. Social theory and fisheries co-management. Marine Policy $22(4-5): 423-436$

Jentoft, Svein, and Siri Ulfdatter Søreng. 2017. Securing sustainable Sami small-scale fisheries in Norway: Implementing the guidelines. In The small-scale fisheries guidelines: Global implementation, ed. Svein Jentoft, Ratana Chuenpagdee, María José Barragán-Paladines, and Nicole Franz, 267-289. Cham: Springer International Publishing.

Jessop, Bob. 1997. The governance of complexity and the complexity of governance: Preliminary remarks on some problems and limits of economic guidance. In Beyond markets and hierarchy: Interactive governance and social complexity, eds. A. Amin and J. Hausner. Cheltenham: Edward Elgar, 111-147, 1997. Published online. 2 December. 2013. https://bobjessop.org/2013/12/02/the-governance-of-complexity-and-thecomplexity-of-governance-preliminaryremarks-on-some-problems-and-limits-of-economic-guidance/. Accessed 7 Sept 2017.

Johnsen, Jahn Petter. 2005. The evolution of the 'harvest machinery': Why capture capacity has continued to expand in Norwegian fisheries. Marine Policy 29 (6): 481-493.

Johnsen, Jahn Petter. 2014. Is fisheries governance possible? Fish and Fisheries 15 (3): 428-444. doi:10.1111/faf.12024.

Johnsen, Jahn Petter, and Bjørn Hersoug. 2014. Local empowerment through the creation of coastal space? Ecology and Society 19 (2). doi:10.5751/ES-06465-190260.

Johnsen, Jahn Petter, Petter Holm, Peter S. Sinclair, and Dean Bavington. 2009a. The cyborgisation of the fisheries. On attempts to make fisheries management possible. Maritime Studies 7 (2): 9-34.

Johnsen, Jahn Petter, Grant Murray, and Barbara Neis. 2009b. North Atlantic fisheries in change-From organic associations to cybernetic organizations. Maritime Studies 7 (2): 55-82.

Johnson, Derek, and Sölmundur Karl Pálsson. 2015. Governability and its discontents in the fishery of Lake Winnipeg since the late 1960s: The view from Gimli. In Interactive governance for small-scale fisheries: Global reflections, ed. Svein Jentoft and Ratana Chuenpagdee, 281-298. Cham: Springer International Publishing. 
Kooiman, Jan, and Maarten Bavinck. 2005. The governance perspective. In In fish for life: Interactive governance for fisheries, ed. Jan Kooiman, Maarten Bavinck, Svein Jentoft, and Roger Pullin. Amsterdam: Amsterdam University press.

Kooiman, Jan, Maarten Bavinck, Svein Jentoft, and Roger Pullin, eds. 2005. Fish for life: Interactive governance for fisheries. Amsterdam: Amsterdam University Press.

Latour, Bruno. 2005. Reassembling the social: An introduction to actor-network-theory. Oxford: Oxford University Press. Lemke, Thomas. 2001. The birth of bio-politics: Michel Foucault's lecture at the college de France on neo-liberal governmentality. Economy and Society 30 (2): 190-207.

Lemke, Thomas. 2007. An indigestible meal? Foucault, governmentality and state theory. Distinktion: Journal of Social Theory 8 (2): 43-64. https://doi.org/10.1080/1600910X.2007.9672946.

Lemke, Thomas. 2015. New materialisms: Foucault and the 'government of things'. Theory, Culture, \& Society 32 (4): 3-25. https://doi.org/10.1177/0263276413519340

Mayhew, Susan. 2009. Governmentality. In A dictionary of geography ed. Susan Mayhew. Oxford: Oxford University Press.

Meld. St. 17 (2014-2015) Evaluering av forvaltningen av kongekrabbe. [Evaluation of king crab management]. Oslo: Nærings- og fiskeridepartementet.

McGoodwin, James R. 1990. Crisis in the world's fisheries: People, problems, and policies. Stanford: Stanford University Press.

Marine Resources Act. 2008. https://www.regjeringen.no/globalassets/upload/FKD/Nedlegg/Diverse/2010/ MarineResourcesAct.pdf. Accessed 7 Sept 2017.

Nedkvitne, Arnved. 1988. Mens bønderne seilte og jektene for. Nord-Norsk og Vest-Norsk kystøkonomi 1500-1750 [NorthNorwegian and West-Norwegian Coastal economy 1500-1750]. Oslo: Universitetsforlaget.

NOU. 2005. Lov om forvaltning av viltlevende marine ressurser: havressursloven'. (NOU 2005:10). [Marine Resources Act draft and report]. Havressurslovutvalgets utredning med lovforslag, Norges offentlige utredninger. Oslo: Statens forvaltningstjeneste, Informasjonsforvaltning. Link to official English translation: https://www.regjeringen.no/ globalassets/upload/FKD/Nedlegg/Diverse/2010/MarineResourcesAct.pdf. Accessed 7 Sept 2017.

NOU. 2008. Retten til fiske i havet utenfor Finnmark. (NOU 2008:8). Utredning fra et utvalg oppnevnt ved kongelig resolusjon 30. juni 2006: [Report about fishing rights in Finnmark] Avgitt til Fiskeri- og kystdepartementet 18. februar 2008. Oslo: Departementenes servicesenter, Informasjonsforvaltning.

Ostrom, Elinor. 1990. Governing the commons: The evolution of institutions for collective action. In The political economy of institutions and decisions. Cambridge: Cambridge University Press.

Ot.prp. nr. 20 (2007-2008) Om lov om forvaltning av viltlevande marine ressursar (havressurslova). The Marine Resources Law bill] Tilråding frå Fiskeri- og kystdepartementet av 21. desember 2007. Oslo: Fiskeri- og kystdepartementet.

Prp. 1857. O. No. 2. Angaaende naadigst Proposition til Norges Riges Storthing betræffende Udfærdigelsen af en Lov om Torsskefiskeriet i Nordlands Amt og Senjens og Tromsø Fogderi.[The 1857 Lofoten Law bill ] https://www. stortinget.no/no/Saker-og-publikasjoner/Stortingsforhandlinger/Lesevisning/?p=1857\&paid=4\&wid=a\&psid= DIVL59\&pgid=a_0047\&s=True. Accessed 7 Sept 2017.

Prp. 1897. Oth. Prp. No. 24. (1896) Om Udfærdigelse af en Lov angaaende Fiskerier i Nordlands og Troms $\varnothing$ Amter [The 1897 Lofoten Law bill]. https:/www.stortinget.no/no/Saker-og-publikasjoner/ Stortingsforhandlinger/Lesevisning/?p=1896\&paid=3\&wid=c\&psid=DIVL64\&pgid=c_0007. Accessed 7 Sept 2017.

Rhodes, R.A.W. 1996. The new governance: Governing without government. Political Studies 44 (4): 652-667. https://doi.org/10.1111/j.1467-9248.1996.tb01747.x.

Smith, Tony, Mark Gibbs, and David Smith. 2009. Fishing for more effective incentives. Science 323 (5912): 337-338. https://doi.org/10.1126/science.323.5912.337b.

Steinberg, Philip. 2001. The social construction of the oceans. New York: Cambridge University Press.

Sønvisen, Signe Annie. 2013. Recruitment to the Norwegian fishing fleet: Storylines, paradoxes, and pragmatism in Norwegian fisheries and recruitment policy. Maritime Studies 12 (1): 1-26. https://doi.org/10.1186/2212-9790-12-8,

Søreng, Siri Ulfsdatter. 2006. Moral discourse in fisheries co-management: A case study of the Senja fishery, northern Norway. Ocean \& Coastal Management 49 (3-4): 147-163. https://doi.org/10.1016/j.ocecoaman.2006.02.008

\section{Submit your manuscript to a SpringerOpen ${ }^{\circ}$} journal and benefit from:

- Convenient online submission

- Rigorous peer review

- Open access: articles freely available online

- High visibility within the field

- Retaining the copyright to your article

Submit your next manuscript at $\gg$ springeropen.com 